\title{
BAHAYANYA SERING MAKAN GORENGAN
}

\author{
Emiliana Harneti Sipul, Muhammad Ali Sodik \\ INSTITUT ILMU KESEHATAN STRADA INDONESIA \\ harnetiemilian@gmail.com, Alisodik2012@gmail.com.
}

\begin{abstract}
ABSTRAK
Gorengan adalah istilah yang mencakup berbagai jenis makanan yang dicelup adonan tepung dan kemudian digoreng rendam dalam minyak goreng panas yang banyak.Semua makanan yang melalui proses penggorengan dan direndam dalam minyak panas tentu sangat nikmat saat dimakan. Terlebih gorengan biasanya memiliki tekstur yang renyah, sehingga akan terasa garing dan nagih ketika digigit. Akan tetapi, perlu Anda ketahui bahwa ada beragam risiko yang mengintai jika sering makan gorengan

Beberapa Dampak Makan Gorengan yang Perlu diperhatikan : Menyebabkan kelebihan berat badan, Meningkatkan risiko penyakit kardiovaskular,Meningkatkan risiko terkena diabetes tipe 2, Memperbesar risiko munculnya kanker, Menambah asupan lemak trans,Meningkatkan risiko berbagai penyakit kronis,

Dan juga ada upaya menghindari menghindari bahaya makan gorengan:

Perhatikan cara menggoreng, Ganti cara memasak.
\end{abstract}

Kata kunci : Gorengan .

\section{Latar Belakang}

warga negara Indonesia secara umum, amat menyukai gorengan, atau penganan yang digoreng. Gorengan salah satu makanan yang murah meriah dan nikmat dimakan kapan saja. Gorengan, salah satu makanan yang jadi favorit banyak orang di tanah air. Rasa yang nikmat dan renyah membuat gorengan banyak disukai masyarakat.Makan gorengan saat hujan atau setelah hujan memang nikmat, apalagi ditemani dengan segelas kopi atau teh hangat.

Namun, tahukah Anda kenikmatan gorengan ternyata tak sebanding dengan efek sampingnya?

Melansir laman Healthline, makanan yang digoreng cenderung tinggi kalori dan lemak trans. Itu sebabnya, makanan tersebut sangat berbahaya bagi kesehatan. .Semua makanan yang melalui proses penggorengan dan direndam dalam minyak panas tentu sangat nikmat saat dimakan. Terlebih gorengan biasanya memiliki tekstur yang renyah, sehingga akan terasa garing dan nagih ketika digigit. Akan tetapi, perlu Anda ketahui bahwa ada beragam risiko yang mengintai jika sering makan gorengan,

Beberapa Dampak Makan Gorengan yang Perlu diperhatikan : Menyebabkan kelebihan berat badan, Meningkatkan risiko penyakit kardiovaskular,Meningkatkan risiko terkena diabetes tipe 2, Memperbesar risiko munculnya kanker, Menambah asupan lemak trans,Meningkatkan risiko berbagai penyakit kronis, 
Dan juga ada upaya menghindari menghindari bahaya makan gorengan:

Perhatikan cara menggoreng, Ganti cara memasak.

\section{Rumusan Masalah}

a.Apa yang di maksud dengan gorengan?

b.Siapa yang mengonsumsi gorengan?

c.Apa saja Dampak makan gorengan ?

b.Bagaimana cara menghindari bahaya makan gorengan?

*.Gorengan adalah istilah yang mencakup berbagai jenis makanan yang dicelup adonan tepung dan kemudian digoreng rendam dalam minyak goreng panas yang banyak.Semua makanan yang melalui proses penggorengan dan direndam dalam minyak panas tentu sangat nikmat saat dimakan. Terlebih gorengan biasanya memiliki tekstur yang renyah, sehingga akan terasa garing dan nagih ketika digigit.

*.warga negara Indonesia secara umum, amat menyukai gorengan, atau penganan yang digoreng. Gorengan salah satu makanan yang murah meriah dan nikmat dimakan kapan saja. Gorengan, salah satu makanan yang jadi favorit banyak orang di tanah air. Rasa yang nikmat dan renyah membuat gorengan banyak disukai masyarakat.Makan gorengan saat hujan atau setelah hujan memang nikmat, apalagi ditemani dengan segelas kopi atau teh hangat.

*.Beberapa Dampak Makan Gorengan yang Perlu diperhatikan : Menyebabkan kelebihan berat badan, Meningkatkan risiko penyakit kardiovaskular,Meningkatkan risiko terkena diabetes tipe 2, Memperbesar risiko munculnya kanker, Menambah asupan lemak trans, Meningkatkan risiko berbagai penyakit kronis.

*.upaya menghindari menghindari bahaya makan gorengan:

Perhatikan cara menggoreng, Ganti cara memasak.

\section{Tinjauan Pustaka}

*.Gorengan sebenarnya bukanlah makanan yang baru. Dalam buku A History of Food (2008) makanan ini bahkan sudah ada sejak 1200 Sebelum Masehi di Mesir. Dari mesir inilah kemudian makanan dengan konsep gorengan menyebar ke seluruh dunia. Di Nusantara sendiri, gorengan ini dibawa oleh China.

*.Gorengan adalah produk makanan yang diolah dengan cara menggoreng dalam minyak.Sebagian zat gizi pada bahan makanan yang digoreng akan rusak selama penggorengan, namun makanan yang digoreng memiliki rasa lebih gurih dan mengandung kalori lebih banyak serta kandungan lemak yang lebih banyak (Paramitha, 2012).

*..Gorengan juga merupakan berbagai jenis makanan yang dicelup adonan tepung dan kemudian digoreng rendam dalam minyak goreng panas yang banyak. 


\section{4.pembahasan}

Semua makanan yang melalui proses penggorengan dan direndam dalam minyak panas tentu sangat nikmat saat dimakan. Terlebih gorengan biasanya memiliki tekstur yang renyah, sehingga akan terasa garing dan nagih ketika digigit. Akan tetapi, perlu Anda ketahui bahwa ada beragam risiko yang mengintai jika sering makan gorengan. Apa saja, ya?

Beberapa Dampak Makan Gorengan yang Perlu diperhatikan :

\section{Menyebabkan kelebihan berat badan}

Makanan yang digoreng akan menyerap lemak dari minyak, sehingga kalorinya akan menjadi lebih tinggi. Semakin tinggi asupan kalori harian seseorang, semakin tinggi pula risiko ia mengalami kelebihan berat badan (overweight) dan obesitas. Selain itu, kandungan lemak trans dalam makanan yang digoreng juga memainkan peran penting dalam penambahan berat badan. Lemak ini diketahui dapat memengaruhi kerja hormon yang dapat meningkatkan nafsu makan dan menambah penyimpanan lemak.

\section{Meningkatkan risiko penyakit kardiovaskular}

Bahaya makan gorengan yang telah banyak diteliti adalah meningkatnya risiko penyakit jantung. Telah diketahui bahwa gorengan dapat meningkatkan risiko terjadinya obesitas, sementara obesitas adalah salah satu faktor risiko penyakit jantung.

Minyak goreng juga mengandung banyak lemak jenuh dan lemak trans yang diketahui dapat meningkatkan kadar kolesterol darah. Peningkatan kolesterol ini bisa menjadi akar dari berbagai penyakit kardiovaskular, termasuk penyakit jantung koroner, serangan jantung, dan stroke.

\section{Meningkatkan risiko terkena diabetes tipe 2}

Makanan yang digoreng biasanya dilapisi tepung. Makanan yang diolah seperti ini akan lebih tinggi kalori dan mengandung lebih banyak karbohidrat sederhana dan lemak tidak sehat. Terlalu banyak lemak dalam makanan tidak hanya dapat menyebabkan penambahan berat badan, tetapi juga meningkatkan risiko terjadinya diabetes tipe 2 . Hal ini bisa terjadi pada siapa saja, termasuk pada anak-anak dan ibu hamil.

\section{Memperbesar risiko munculnya kanker}

Bahaya makan gorengan yang juga tidak bisa diremehkan adalah meningkatkan risiko terkena kanker. Bahaya ini bisa muncul akibat zat akrilamida yang dapat terbentuk selama proses memasak dengan suhu tinggi, seperti menggoreng. Makanan bertepung, seperti ayam goreng tepung dan 
sebagainya, diketahui akan mengandung akrilamida yang lebih tinggi ketika terpapar suhu tinggi. Jika terlalu banyak dan sering dikonsumsi, zat ini diduga bisa menyebabkan beberapa jenis kanker, seperti kanker ovarium.

\section{Menambah asupan lemak trans}

Ada dua jenis lemak trans. Pertama, lemak trans alami yang hadir dalam jumlah sedikit di dalam makanan, seperti daging dan produk susu. Kedua, lemak trans buatan yang terbentuk ketika lemak jenuh melalui proses hidrogenasi, yang muncul saat makanan digoreng pada suhu tinggi. Proses ini akan mengubah struktur kimiawi lemak, sehingga nantinya akan lebih sulit untuk dicerna oleh tubuh. Alhasil, akan timbul berbagai efek buruk bagi kesehatan akibat kandugan lemak trans. Mulai dari meningkatnya risiko penyakit jantung, kanker, diabetes, hingga obesitas.

\section{Meningkatkan risiko berbagai penyakit kronis}

Hobi makan gorengan menempatkan Anda pada risiko tinggi untuk terserang penyakit kronis, seperti penyakit jantung, diabetes, dan obesitas. Memang sering tidak disadari, makan gorengan bisa meningkatkan tekanan darah, berat badan, dan menurunkan kadar kolesterol "baik" atau HDL. Kesemua hal tersebut merupakan faktor risiko terjadinya penyakit jantung.

\section{Beberapa Upaya Menghindari Bahaya Makan Gorengan :}

Ganti dengan minyak yang lebih sehat

Cara terbaik yang bisa Anda lakukan adalah dengan mengganti minyak goreng Anda dengan jenis minyak yang lebih sehat, seperti minyak zaitun, minyak kelapa, dan minyak alpukat. Sementara itu, jenis minyak yang tidak disarankan untuk menggoreng makanan adalah minyak yang tinggi asam lemak tak jenuh, seperti minyak kedelai, minyak jagung, minyak kanola, minyak wijen, dan minyak bunga matahari. Hal yang juga tak kalah penting dalam meminimalisir bahaya dari makanan yang digoreng adalah dengan menghindari penggunaan minyak secara berulang. Lebih disarankan, minyak hanya digunakan sekali pakai dalam menggoreng.

\section{Perhatikan cara menggoreng}

Agar minyak tidak menyerap ke dalam makanan yang digoreng, disarankan untuk menggoreng makanan pada suhu $176-190^{\circ} \mathrm{C}$. Anda bisa menggunakan termometer khusus penggorengan untuk mengetahui ini. Suhu menggoreng penting untuk diperhatikan, karena suhu minyak terlalu tinggi bisa merusak minyak dan menghasilkan radikal bebas yang berpengaruh buruk bagi kesehatan dalam jangka panjang. Sementara itu jika suhu lebih rendah, minyak akan meresap ke dalam makanan dan membuat makanan jadi lebih berlemak. Setelah menggoreng disarankan pula untuk 
meniriskan makanan dengan tisu kertas agar minyak yang berlebih pada permukaan makanan dapat diserap.

Ganti cara memasak

Agar lebih sehat, alih-alih menggoreng makanan, cobalah untuk memanggangnya. Makanan yang dipanggang juga bisa menjadi renyah dan sama lezatnya dengan gorengan. Sebelum memanggang, lapisi makanan dengan bumbu atau rempah-rempah agar rasanya lebih lezat. Sebagian besar protein hewani, seperti daging sapi, daging ayam, dan ikan, juga mengandung banyak lemak yang bisa keluar saat dipanaskan di wadah masak yang antilengket. Jadi, Anda bisa memanfaatkan lemak alami untuk memasak makanan tanpa harus menambahkan minyak goreng. Sekarang ini terdapat alat menggoreng tanpa minyak (air fryer). Meski harganya lebih mahal, alat ini bisa menjadi pilihan untuk hidup yang lebih sehat. Jika Anda ingin mengonsumsi gorengan, sebaiknya buatlah sendiri gorengan di rumah daripada membelinya. Gorengan yang dibuat di rumah cenderung lebih sehat karena Anda dapat dengan bijak memilih minyak serta cara menggorengnya.

\section{Kesimpulan}

warga negara Indonesia secara umum, amat menyukai gorengan, atau penganan yang digoreng. Gorengan salah satu makanan yang murah meriah dan nikmat dimakan kapan saja. Gorengan, salah satu makanan yang jadi favorit banyak orang di tanah air. Rasa yang nikmat dan renyah membuat gorengan banyak disukai masyarakat.Makan gorengan saat hujan atau setelah hujan memang nikmat, apalagi ditemani dengan segelas kopi atau teh hangat. Beberapa Dampak Makan Gorengan yang Perlu diperhatikan : Menyebabkan kelebihan berat badan, Meningkatkan risiko penyakit kardiovaskular,Meningkatkan risiko terkena diabetes tipe 2, Memperbesar risiko munculnya kanker, Menambah asupan lemak trans,Meningkatkan risiko berbagai penyakit kronis. *.upaya menghindari menghindari bahaya makan gorengan:

Perhatikan cara menggoreng, Ganti cara memasak.

\section{Daftar Pustaka}

Sodik, M. A., Suprapto, S. I., \& Pangesti, D. (2013). Faktor-Faktor Yang Berhubungan Dengan Pelaksanaan Pelayanan Prima Pegawai Di Rsui Orpeha Tulungagung. STRADA Jurnal Ilmiah Kesehatan, 2(1), 24-32.

Putri A.( 2021,Maret 08) " Dampak Makan Gorengan Bagi Kesehatan dan Cara Menyiasati " http://ners.unair.ac.id/site/index.php/news-fkp-unair/30-lihat/727-dampak-makan-gorengan-bagikesehatan-dan-cara-menyiasati

https://id.m.wikipedia.org/wiki/Gorengan 